DOI 10.22363/2312-9220-2020-25-3-479-486

UDC 821.16.1

Research article

\title{
Sherlock Holmes and Erast Fandorin: the peculiarities of Akunin's dialogue with Conan Doyle
}

\author{
Oxana V. Afanasyeva ${ }^{1}$, Kamilla F. Gereikhanova ${ }^{2}$ \\ ${ }^{1}$ Moscow Information and Technological University - \\ Moscow Architecture and Construction Institute \\ 32 Volgogradskii Ave, bldg 11, Moscow, 129164, Russian Federation \\ ${ }^{2}$ Institute of International Law and Economics named after A.S. Griboedov \\ 21 Entuziastov Highway, Moscow, 111024, Russian Federation
}

\begin{abstract}
The article analyzes the receptions of A.C. Doyle's masterpieces and the circle of novels "Fandorin" by Boris Akunin. Based on the analysis of the works "Azazel", "Decorator", "Scarpei Baskakovs", "Prisoner of the Tower", a number of conclusions are made about the specifics of B. Akunin's intertextual strategy. It is shown that the intertextual dialogue between Akunin and Conan Doyle is carried out through character and narrative projections, in particular, structural stylization, the transposition of the plot on Russian soil, etc. The ambiguous role of Conan Doyle receptions, performing, firstly, the para-genre (detective) function of plot-semantic coding, secondly, the function of the transtextual riddle, the solution of which lies outside the work - in the Conan Doyle pretext, thirdly, the function of a parody imitation of the predecessor's stylistic manner, including the specifics of Russian translations of short stories about Sherlock Holmes, is revealed.
\end{abstract}

Keywords: intertextual dialogue, Arthur Conan Doyle, Sherlock Holmes, Boris Akunin, Fandorin, Dr. Watson, reception, allusion, detective

\section{Introduction}

Recently, the work of Boris Akunin is on the focus of research attention. In the aspect of our topic, the work is devoted to the analysis of the postmodern attitudes of modern Russian prose [1-4], and the research of intertextual strategies of B. Akunin, including the game techniques used by the writer in his novels [5-7]. However, some research gaps remain. So, in theoretical terms, the dialogic functions of the intertext have not yet been fully explored.

The purpose of this article is to analyze B. Akunin's intertextual appeal to the work of Arthur Conan Doyle as part of a unique author's strategy for building text that ensures success among the widest readership.

(C) Afanasyeva O.V., Gereikhanova K.F., 2020

c. (i) This work is licensed under a Creative Commons Attribution 4.0 International License https://creativecommons.org/licenses/by/4.0/ 


\section{Scientific content and methods}

Most of the works of the "Fandorin series" (in fact, all works, except those where the plot is not the intellectual work of finding a criminal, but chases, shootings, a quick change of events) can be considered a reference to the stereotype of a classic British detective story. Akunin's typical features of a classic British detective story undergo a peculiar refraction, which implies a game and often a parody. Thus, the writer himself, in a review of the book by Elizabeth George, "The Payback with Blood," called himself "a bruised British classic detective" [8. P. 3], which partially reflects on the genre subtexts of the entire "Fandorin" corpus of texts: it contains much more genre features British detective.

\section{Review}

The proximity of Akunin's texts to the literary heritage of Conan Doyle is noted by various researchers. So, G.V. Mishina and T.A. Tsygankov noted that "B. Akunin, introducing the characters of A. Conan Doyle into his works, shows how close Sherlock Holmes and Fandorin are" [9. P. 220]. Researcher A.V. Kazachkova determined that "like Sherlock Holmes, who uses cocaine and plays the violin $<\ldots>$ Erast Petrovich Fandorin at Akunin owns oriental martial arts, sorting out jade rosaries, draws hieroglyphs and takes a bath with ice" [10. P. 66].

N. Potanina, analyzing the "Fandorin project", writes about literary classics as the main source of Akunin's intertextuality: "Conan Doyle, Chesterton and Agatha Christie are usually listed in the extensive list of literary sources of the famous 'project'. Some add to this Stevenson series. Because without Conan Doyle and Chesterton, there would be no detective intrigue in Akunin's novels, without Stevenson's searches for treasures and a 'suicide club', and without Agatha Christie the very principle of placing all these attributes of adventure fiction in a lived-in literary space of a respectable reader classics" [11].

B. Akunin resorts to interacting with the genre of the classic detective story at several levels of the text. At the same time, the Conan Doyle receptions in the text of the "Fandorin series" are multifunctional and fulfill, firstly, the para-genre (detective) function of the plot-semantic coding, and secondly, the function of the transtextual riddle, the solution of which lies outside the work - in the Conan Doyle pretext.

This approach fits into the postmodern paradigm, in which, as A.G. Kovalenko notes, "freedom from a strict plot allows the writer to create 'variants' and 'versions' of the narrative within one work, and the reader is left to decide which of the plots corresponds more to the logic of the work, and which does not" [1. P. 268].

\section{Research results}

So, already the first novel of the "Fandorin series" - "Azazel" contains a culturalaxiological roll-call with the work of Conan Doyle at the level of topos. The cultural name "London" in the art space of "Azazel" is played out through the prism of the idea of "criminal London" formed in a series of stories about Sherlock Holmes, whose internal topography contributes to both the development of crime and the disclosure of crimes. Borrowing plot space from the case-law texts of Conan 
Doyle, Akunin sets the primary coordinates for immersion in the text. The fashion of Fandorin's existence in London is a constant sense of danger, persecution, and surveillance: "The people on the road looked past, not one looked in their face, which, you see, would be absolutely unimaginable in Moscow. But at the same time, Fandorin did not leave a strange feeling, as if someone had an unkind look on his back. Several times the young man looked around and once seemed to notice how a figure in black staggered behind a theater stand" [12. P. 188]. But at the same time, London becomes for Fandorin a city that activates the opposition of "knowledge/ignorance": moving to each new location of this city changes Fandorin's view of the case under investigation and adds knowledge about the investigation.

The novel "Azazel" also contains an element of the author's ironic game with a reader's perception and at the same time an intergenre reference to the image of the cinematic "Russian Holmes", which appears in the scene of Fandorin's surveillance of Bezhetskaya's servant: "At a quarter to ten, closing with the Times number and a hole verified for review, Erast Petrovich was already sitting in the lobby of the 'Winter Queen' " [12. P. 131]. Dr. Watson uses the same trick in the movie "The Adventures of Sherlock Holmes and Dr. Watson", in the series "Meet" trying to keep track of Holmes, Watson takes a newspaper with a hole.

A considerable intertextual richness realized through character and narrative projections to the story "The Hound of the Baskervilles" of A. Conan Doyle is possessed by B. Akunin's story "The Scarpea of the Baskakovs", included in the collection "Jade Rosary".

"The Baskakovs' Scarpea" actually duplicates "The Hound of the Baskervilles" starting with the onomastic game in the heading complex (identity of the first letters of the words that make up the name). The intertextual dialogue between the two works continues in the motive of the "family legend" about a certain ancestor of this kind (Hugo Baskerville at Conan Doyle and St. Pankratius, a former Baskak at Akunin), who first met this monster. An explicit allusion to "The Hound of the Baskervilles" are key images of a mentally unstable owner of the estate and a malicious falsifier claiming to be an inheritance.

It is characteristic that the mystery crime is not directed by the main character himself - the detective (Sherlock Holmes/Erast Fandorin), but his assistant (Dr. Watson/Anisy Tulpanov). At the same time, the assistant writes letters of report to his boss, and at the time of the decisive battle, the detective himself appears at the scene, making up under the tramp. The assistant lives in the house of the owners of the estate, has his own version of crimes, which turns out to be incorrect, but helps the detective get on the right track.

Tulpanov arrives in Bogomilovo to investigate the case of the Baskakovs' family curse: "That's great. So tomorrow you will go to Pakhrinsky district. There they appeared some unprecedented anaconda. The dean father writes about the machinations of St. Satan and complains about the godlessness of the zemstvo authorities, and the chairman of the zemstvo council complains that the church stirs up passions and indulges superstition. Go there and sort things out" [13. P. 220].

It is noteworthy that the exact same situation is in "The Hound of the Baskervilles", where the investigation is passed into the hands of Dr. Watson: "I will be happy to go to Baskerville Hall," I replied, "and I will not regret the time spent". 
"You will send me detailed reports," said Holmes. "At the most critical moment - and he will inevitably come - I will supervise your actions. I think that departure can be scheduled for Saturday" [14. P. 221].

As noted the researcher A.G. Golovacheva, "in the course of the investigation carried out by Tulpanov, a fraudulent move arises that goes back to another work of Conan Doyle - 'The Adventure of the Speckled Band' " [15. P. 78]. In "The Baskakovs' Scarpe", another victim of the crime - the clerk of the estate is found in the following form: "He sat limp on a chair and threw back his head. He was dressed in something broad, baggy, like a patterned Asian robe. The wide robe moves in a strange way. It was not a robe, but an unprecedented snake, wrapped around a corpse" [13. P. 239]. In "The Adventure of the Speckled Band", Dr. Roylott's death was similarly depicted: "He sat with his chin up, his eyes fixed on the ceiling. An unusual yellow ribbon with brown dots wrapped around his head. A strange headgear moved, and the faceted head of a terrible snake rose from Dr. Roylott's hair" [14. P. 93].

In general, the intertextuality strategy in "The Baskakovs' Skarpea" is similar to the translation-retelling technology (like a pair of Pinocchio - Buratino or Doctor Doolittle - Doctor Aibolit): the author, as it were, transposes the plot into Russian soil, replacing a number of realities and iconic details. However, in the case of children's works transferred to Soviet soil, the authors were guided by differences in realities, replacing in the text everything that could be incomprehensible or unacceptable to the Soviet reader. Akunin, however, transfers the plot not only for the purpose of encoding a detective puzzle, which an attentive reader can solve: he simultaneously transfers the plot and implements a parody imitation of the corresponding translation manner.

The intertextual dialogue with the work of Arthur Conan Doyle is also the story of B. Akunin "Decorator", dedicated to the adventures of Jack the Ripper in Russia.

Organization of intertextual connections of the "Decorator" with the precedent story by Arthur Conan Doyle "Murder in Abby Grange" is realized through borrowing and adapting images, paraphrasing motives and plot situations, quotation, reminiscence and allusion references both in the author's narrative and in the characters' speech.

The reminiscence mechanism of interaction is most evident in the scene of the "trial" of the criminal. So, we read at Akunin: "Everything was ready for the trial. The defendant in a women's dress, but without a hat, limp, sat in an armchair. An impressive bump poured purple on his forehead. Nearby, arms crossed on his chest, stood a bailiff - Masa. Erast Petrovich decided to be a judge to Angelina, he took on the role of the prosecutor himself" [16. P. 190].

Conan Doyle's "trial" is organized as follows: the defendant is the murderer of Sir Brackenstall, Captain Crowker, the role of the jury is played by Dr. Watson, Holmes himself assumes the role of judge:

"Do you know what we will do now? We will judge you as required by law. You, Captain Crowker, are the defendant. You, Watson, an English jury, I don't know a person who would be more worthy of this role. I am a judge" [17].

The plot conflicts and similar details of the narrative "explicitly send the story "Decorator" by B. Akunin to A. Conan Doyle's specific story "Murder in Abby 
Grange" (crime details, scene of "lynching", close to direct quotation, numerous allusions), and to the corps of detectives A. Conan Doyle and the poetry of the detective genre as a whole (the motives of the investigation conducted in parallel with the police, a "false trace", etc.).

The hero of the "Decorator" is a philosopher who believes that his actions help outwardly ugly people to discover their inner beauty: "I wish you well. I have enough love for everyone. I see Beauty under lousy clothes, under the scab of unwashed bodies, under scabies and rashes" [16. P. 114]. In Conan Doyle's story, the idea of a good outcome for the murder comes from the heroes themselves: maid Teresa and Lady Brackenstall talk about the incredible brutality of the murdered Sir Eustace. The murderer, Captain Crowker, also speaks of the same thing: "This wild beast ruthlessly tormented and tormented the woman whom I loved more than my life" [17].

It is significant that the intertext dialogue in this case is realized also due to the expressive function of the intertext, referring to the case-law detective A. Conan Doyle as a text source with already formed figurative-expressive, emotionallyevaluative elements and a set of moral problems.

A somewhat different aspect of the interaction of the text of the "Fandorin cycle" by B. Akunin with the corpus of texts by A. Conan Doyle can be seen in the novel "The Prisoner of the Tower, or The Short, but Beautiful Path of the Three Wise", in which Erast Fandorin, Arsen Lupine and Sherlock Holmes meet. The semantic moves "Tower Prisoners" demonstrate poly-intertextuality through the combination of ironic receptions of Conan Doyle motifs in combination with the previously created parody intertext "Herlock Scholms was late" by Maurice Leblanc.

The specifics of B. Akunin's author's strategy forms in "The Prisoner of the Tower" a multi-layer image of Sherlock Holmes himself, which is a conglomerate of images of the literary and cultural "Russian" Holmes that was formed during the $19^{\text {th }}$ and first half of the $20^{\text {th }}$ century. At the same time, the appearance of Sherlock Holmes and Erast Fandorin in a single artistic space creates additional meaning due to the motive of duality.

The intertextual connection with the works of Conan Doyle can also be considered that the novel "The Prisoner of the Tower" is mainly "written" by Dr. Watson (Уотсон). It is he who tells of the exploits of Holmes in the pages of Doyle's novels. It is noteworthy that Akunin uses exactly this variant of writing the name of the doctor, although in the Russian tradition there are two variants of writing Dr. Watson (Ватсон) and Dr. Watson (Уотсон). There is no final answer to the question of whether Watson (Ватсон) or Watson (Уотсон) is right: there is no direct analogue of the letter $W$ in the Russian alphabet, proper names beginning with it are transliterated in different ways (cf. William (Вильям) / William (Уильям) Shakespeare). Behind Watson (Уотсон) is the tradition, first of all, of one of the most reprinted translations - Nikolai and Marina Chukovsky. The Watson (Ватсон) variant is characteristic of the "tabloid" adaptations of Sherlock Holmes novels and cinema. Thus, referring to the specifics of Russian translations of stories about Sherlock Holmes, B. Akunin continues the game with the reader, contrasting the "literary Holmes" and "Holmes of mass culture". 
Partial parallelism of the images of Watson and Fandorin's faithful helper Masahiro Shibata (Masa) is reinforced in "The Prisoner of the Tower": Masa becomes Fandorin's biographer, taking lessons from Dr. Watson, but does not succeed in this: "On the manuscript of Masahiro Shibata's story from the side, it's written in cursive: 'Mr. read my essay and took the word of honor from me that, while he is alive, I will never again describe his exploits on paper. What a pity! I like being a writer so much...'" [13. P. 703].

From the point of view of the plot-semantic and stylistic reception of the work of A. Conan Doyle, obvious politicity, "The Prisoner of the Tower" is a kind of metatext in which B. Akunin's most characteristic intertextual strategies are implemented.

\section{Conclusion}

Summarizing the study receptive mechanisms of the interaction of the works of the "Fandorin series" of B. Akunin with the classic English detectives of A. Conan Doyle, it can be stated that intertextual penetration is multilevel and multifunctional, and also includes the whole spectrum of postmodern techniques: from using story archetypes of the English detective story, collage architectonics, character and narrative projections to transtextual riddles and semantic coding. Thus, Boris Akunin's intertextual strategy makes it possible to include many multicultural texts and discursive practices in the range of reader associations.

\section{References}

[1] Kovalenko, A.G. (2015). Uroki postmodernizma i sovremennaya proza [Lessons from postmodernism and modern prose]. Russkiy yazyk i literatura v prostranstve mirovoy kul'tury [Russian language and literature in the space of world culture]: Materials of the XIII Congress MAPRYAL (pp. 267-270). Moscow.

[2] Meskin, V.A. (2014). Realizm - postmodernizm v rossiyskoy literature vchera i segodnya [Realism - postmodernism in Russian literature yesterday and today]. Bulletin of the Peoples' Friendship University of Russia. Series: Literary Studies. Journalism, (4), 5-10.

[3] Soldatkina, Ya.V. (2018). Time and space of contemporary Russian prose: newmodernism and postmodernism (review of the study guide: Krotova D.V. Modern Russian literature. Post-modern and "New-modern". M.: MAKS Press, 2018. 224 p.). RUDN Journal of Studies in Literature and Journalism, 23(4), 477-482. http://dx.doi.org/ 10.22363/2312-9220-2018-23-4-477-482

[4] Desyatov, V., \& Karpukhina, V. (2019). Metafizika detektiva (o romane Borisa Akunina "Sedmitsa Trekhglazogo") [Metaphysics of a detective (about the novel by Boris Akunin "The Three-eyed Weekly")]. Sibirskiy filologicheskiy zhurnal [Siberian Journal of Philology], (1), 134-147.

[5] Tang, Sh. (2017). Features of game poetics in "The Death of Achilles" by Boris Akunin. RUDN Journal of Studies in Literature and Journalism, 22(4), 614-626. http:// dx.doi.org/10.22363/2312-9220-2017-22-4-614-626

[6] Tang, Sh. (2019). Theatricality in the postmodern novel "Quest" by B. Akunin. RUDN Journal of Studies in Literature and Journalism, 24(3), 390-403. http://dx.doi.org/ 10.22363/2312-9220-2019-24-3-390-403

[7] Tang, Sh. (2017). Game Strategy of "The Spy Novel” by Boris Akunin. RUDN Journal of Studies in Literature and Journalism, 22(3), 457-465. http://dx.doi.org/10.22363/ 2312-9220-2017-22-3-457-465 
[8] Akunin, B. (2008). Dzhordzh E. Rasplata krov'yu [George E. The reckoning of blood]. Moscow, Eksmo Publ.

[9] Mishina, G.V., \& Tsygankova, T.A. (2019). Zaimstvovaniya literaturnykh obrazov v romanakh B. Akunina ob Eraste Fandorine [Borrowing literary images in B. Akunin's novels about Erast Fandorin]. Perspektivy razvitiya sovremennogo gumanitarnogo znaniya [Prospects for the development of modern humanitarian knowledge]: Collection of materials of the International scientific and practical conference] (pp. 216-222). Sterlitamak.

[10] Kazachkova, A.V. (2015). Zhanrovaya strategiya detektivnykh romanov Borisa Akunina 1990 - nachala 2000-h gg. [Genre strategy of detective novels by Boris Akunin in the 1990s and early 2000s] (Dissertation of the Candidate of Philological Sciences). Retrieved December 21, 2019, from http://cheloveknauka.com/zhanrovaya-strategiyadetektivnyh-romanov-borisa-akunina-1990-nachala-2000-h-gg\#ixzz5I1BULVJ1

[11] Potanina, N. (2004). Dikkensovskiy kod "fandorinskogo proyekta" [Dickens code of the "Fandorin project"]. Voprosy literatury [Literature Issues], (1), 220-227.

[12] Akunin, B. (1998). Azazel. Retrieved February 2, 2020, from http://www.akunin.ru/ knigi/fandorin/erast/azazel/glava10/

[13] Akunin, B. (2007). Nefritovye chetky [Jade rosary]. Moscow, Zakharov Publ.

[14] Conan Doyle, A. (1980). Zapiski o Sherloke Kholmse [The Memoirs of Sherlock Holmes]. Leningrad, Detskaya literature Publ.

[15] Golovacheva, A.G. (2015). "Skarpeya Baskakovykh” B. Akunina: Konan Doyl v sodruzhestve s Chekhovym ["The Scarpey of the Baskakovs" by B. Akunin: Conan Doyle in Commonwealth with Chekhov]. Voprosy russkoy literatury [Questions of Russian Literature], 1(31), 77-87.

[16] Akunin, B. (1999). Osobyye porucheniya [Special assignments]. Moscow, Zakharov Publ.

[17] Conan Doyle, A. (1975). Ubiystvo v Ebbi-Greyndzh [The Adventure of the Abbey Grange]. Retrieved February 2, 2020, from http://lib.ru/AKONANDOJL/sh_ebbig.txt/

\section{Article history:}

Received: 3 June 2020

Revised: 8 June 2020

Accepted: 15 June 2020

\section{For citation:}

Afanasyeva, O.V., \& Gereikhanova, K.F. (2020). Sherlock Holmes and Erast Fandorin: The peculiarities of Akunin's dialogue with Conan Doyle. RUDN Journal of Studies in Literature and Journalism, 25(3), 479-486. http://dx.doi.org/10.22363/2312-92202020-25-3-479-486

\section{Bio notes:}

Oxana V. Afanasyeva, Candidate of Philology, senior teacher of the Department of Foreign Languages of the Faculty of Humanities of the Moscow Information and Technological University - Moscow Architecture and Construction Institute. E-mail: oxana4u2014@yandex.ru

Kamilla F. Gereikhanova, Candidate of Philology, Associate Professor of the Department of History of Journalism and Literature of the Faculty of Journalism of the Institute of International Law and Economics named after A.S. Griboedov. E-mail: kamilla. gereykhanova@mail.ru 


\title{
Шерлок Холмс и Эраст Фандорин: об особенностях акунинского диалога с Конан Дойлом
}

\author{
О.А. Афанасьева ${ }^{1}$, К.Ф. Герейханова ${ }^{2}$
}

${ }^{1}$ Московский информационно-технологический университет -

Московский архитектурно-строительный институт

Российская Федерация, 129164, Москва, Волгоградский пр-кт, д. 32, к. 11

${ }^{2}$ Институт международного права и экономики имени А.С. Грибоедова

Российская Федерация, 111024, Москва, шоссе Энтузиастов, 21

\begin{abstract}
Аннотация. В статье исследуются рецепции А.К. Дойла в повестях и романах фандоринского цикла Бориса Акунина. На основе анализа произведений «Азазель», «Декоратор», «Скарпея Баскаковых», «Узница башни» делается ряд умозаключений о специфике интертекстуальной стратегии Б. Акунина. Демонстрируется, что интертекстуальный диалог Акунина с Конан Дойлом осуществляется через персонажные и нарративные проекции, в частности, структурную стилизацию, транспозицию сюжета на русскую почву и пр. Выявляется многозначная роль конан-дойловских рецепций, выполняющих, во-первых, паражанровую (детективную) функцию сюжетно-семантического кодирования, во-вторых, функцию транстекстуальной загадки, разгадка которой лежит вне произведения - в конан-дойловском претексте, в-третьих, функцию пародийной имитации стилистической манеры предшественника, включая специфику русских переводов рассказов о Шерлоке Холмсе.
\end{abstract}

Ключевые слова: интертекстуальный диалог, Артур Конан Дойл, Шерлок Холмс, Борис Акунин, Фандорин, доктор Уотсон, рецепция, аллюзия, детектив

\section{История статьи:}

Дата поступления в редакцию: 3 июня 2020 г.

Дата принятия к печати: 15 июня 2020 г.

\section{Для цитирования:}

Afanasyeva O.V., Gereikhanova K.F. Sherlock Holmes and Erast Fandorin: the peculiarities of Akunin's dialogue with Conan Doyle // Вестник Российского университета дружбы народов. Серия: Литературоведение. Журналистика. 2020. Т. 25. № 3. С. 479-486. http://dx.doi.org/10.22363/2312-9220-2020-25-3-479-486

\section{Сведения об авторах:}

Афанасьева Оксана Васильевна, кандидат филологических наук, доцент кафедры иностранных языков гуманитарного факультета Московского информационнотехнологического университета - Московского архитектурно-строительного института. E-mail: oxana4u2014@yandex.ru

Герейханова Камилла Фезамеддиновна, кандидат филологических наук, доцент кафедры журналистики и литературы факультета журналистики Института международного права и экономики имени А.С. Грибоедова. E-mail: kamilla.gereykhanova@mail.ru 